\title{
RECONNAISSANCE OF THE GLACIERS OF THE SUSITNA RIVER BASIN IN CONNECTION WITH PROPOSED HYDROELECTRIC DEVELOPMENT
}

W. D. Harrison,

(Geophysical Institute, University of Alaska, Fairbanks, Alaska 99701, U.S.A.)

B. T. Drage,

(Peratrovitch and Nottingham, Inc., 1506 West 36 Avenue, Anchorage, Alaska 99503, U.S.A.)

S. Bredthauer,

(R \& M Consultants, Inc., 5024 Cordova Street, Anchorage, Alaska 99501, U.S.A.)

D. Johnson,

(Geophysical Institute, University of Alaska, Fairbanks, Alaska 99701, U.S.A.)

C. Schoch

(R \& M Consultants, Inc., 5024 Cordova Street, Anchorage, Alaska 99501, U.S.A.)

and A. B. Follett

(North Pacific Aerial Surveys, 4241 "B" Street, Suite 101, Anchorage, Alaska 99503, U.S.A.)

ABSTRACT

A reconnaissance program has been carried out to identify problems caused by glaciers in a large proposed hydroelectric development in the Susitna River basin of Alaska. Balance measurements on the major glaciers have been initiated, and long-term balance between 1949 and 1930 has been estimated from existing photo sets. From the latter it appears that shrinking of the glaciers, which comprise $4 \%$ of the basin area, may have contributed appreciably to the measured basin runoff. A potential instability in the drainage of Eureka Glacier, on the edge of the basin, has been identified. The glaciers of the basin seem to be largely temperate, and most of them are surging or pulsing types. Velocity measurements show seasonal variations that suggest appreciable contribution to the motion from basal sliding. A study of the moraines of Susitna Glacier, which is a surging type, indicates that no surge is imminent. Glacier-dammed lakes exist in the basin; they are small but could be enlarged by surging or other mechanisms. Some general problems in the estimation of the transport of suspended sediment are noted.

\section{INTRODUCTION}

The Susitna River is the sixth largest in Alaska, and its extensive hydroelectric potential has been recognized for some years. In December 1979, the Alaska Power Authority commissioned a detailed feasibility study in order to determine technical feasibil- ity, economic viability, and environmental impacts of the optimal development of the basin (Acres American 1982). This paper describes the results of a reconnaissance program designed to identify any problems caused by the existence of glaciers in the basin ( $R$ \& M Consultants 1981). Glaciers cover about $4 \%$ of the area proposed for development.

The headwaters of the Susitna River are on the south side of the central Alaska Range, from which the river flows south across a broad alluvial fan for about $80 \mathrm{~km}$ before turning west into a deep canyon, where it flows for $120 \mathrm{~km}$. It then turns south and flows another $200 \mathrm{~km}$ to Cook Inlet (Fig.1). The total drainage area of the river is about $50000 \mathrm{~km}^{2}$; the area proposed for development is about one third of this. The longest period of available streamflow data is for the station at Gold Creek (1949 to present, see Figure 1). At Gold Creek the average flow is $271 \mathrm{~m}^{3} \mathrm{~s}^{-1}$; winter and summer flows are 59.5 and $573 \mathrm{~m}^{3} \mathrm{~s}^{-1}$, respectively.

The proposed plan of development contains two reservoirs, Watana and Devil Canyon (Fig.1). Watana, the upstream reservoir, is the larger of the two, extending $77 \mathrm{~km}$ upstream from the site of the dam. It has a surface area of $158 \mathrm{~km}^{2}$, an altitude of $656 \mathrm{~m}$, a maximum depth of about $207 \mathrm{~m}$ at normal operating level, and a volume of $1.2 \times 10^{10} \mathrm{~m}^{3}$. The Watana dam would be an earthfill structure with a maximum height of $270 \mathrm{~m}$, among the highest in the world, a crest length of $1250 \mathrm{~m}$, and a total volume of about $47 \times 10^{6} \mathrm{~m}^{3}$. The initial capacity of Watana 


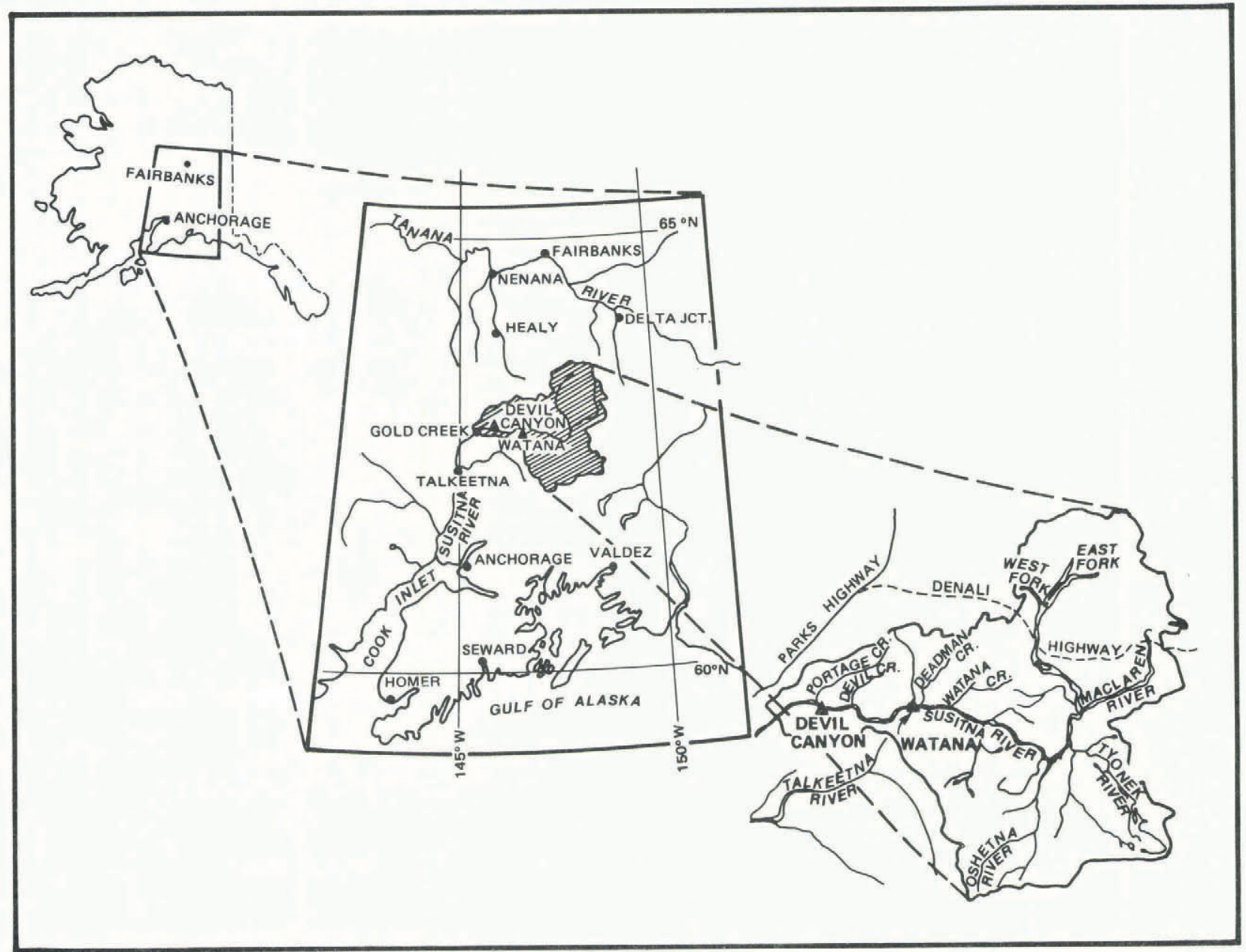

Fig.1. Location map (Acres American 1982).

will be $680 \mathrm{MW}$, with $340 \mathrm{MW}$ to be added shortly thereafter. Its average annual energy production is estimated at $3450 \mathrm{GW} \mathrm{h}$. Devil Canyon reservoir is about $42 \mathrm{~km}$ long. It has a surface area of about $32 \mathrm{~km}^{2}$, an altitude of $445 \mathrm{~m}$, a maximum depth of about $168 \mathrm{~m}$, and a volume of $1.4 \times 10^{9} \mathrm{~m}^{3}$. The reservoir will be formed by a double-curved thin arch concrete dam with a maximum height of $197 \mathrm{~m}$. Its average annual energy production is estimated at $3340 \mathrm{GW} \mathrm{h}$. The total cost for the proposed Susitna project is estimated at $\$ 5.1 \times 10^{9}$. If constructed, it will provide a major portion of the electrical energy that is required for the Anchorage-Fairbanks corridor far beyond $2000 \mathrm{AD}$.

The importance of glaciers within the basin is expected to be greater than suggested by the $4 \%$ area of glacierization for several reasons (Meier and Tangborn 1961, Meier 1969). These include high precipitation, water storage and release by glaciers, sediment production, glacier-caused floods, and effects of glacier surges. The largest of the basin glaciers is West Fork (Fig.2), which is about $48 \mathrm{~km}$ long and $3.2 \mathrm{~km}$ wide. Susitna Glacier is roughly the same size, if its complicated system of tributaries is included (Fig.2). The terminal areas of the glaciers lie at altitudes which are about $1070 \mathrm{~m} \mathrm{a.s.1.;} \mathrm{the} \mathrm{late}$ summer snowline was at about $1830 \mathrm{~m}$ in 1981. The glaciers have been wasting strongly in recent years. Most, if not all, of the major glaciers are unstable in their flow and are subject to surging. Apparently all previous knowledge of these glaciers has been obtained from aerial photography.

\section{HYOROLOGY}

Although glaciers cover only $4 \%$ or so of the Susitna basin, together with the adjacent mountain terrain they seem to contribute a disproportionate fraction of the average annual streamflow. Roughly $33 \%$ of the streamflow at Gold Creek originates above gaging stations on the Maclaren and Susitna rivers at the Denali Highway, although the upstream area represents only $20 \%$ of the basin area (Fig.1). The following topics need to be viewed in this context.

\subsection{Glacier mass balance}

Reconnaissance mass balance measurements were made on most of the major glaciers in the basin. With the limited resources available it was felt that these measurements would not be able to determine the net balances very accurately, but would supply useful estimates of the size of winter and summer balances, permit a comparison between the mass balance and altitude relationships of the basin glaciers, and, equally important, provide the nucleus of a database that might permit the establishment of a relationship between the balances of the glaciers of the Susitna basin and that of Gulkana Glacier $69 \mathrm{~km}$ to the east, also on the south side of the Alaska Range, for which balance data since 1966 are available. These sites are shown in Figure 2; the data are shown in Figure 3. The winter snowpack was surveyed by two mountaineers, usually travelling on skis, in May 1981. The results were obtained by measuring the snow depth above the 1980 late-summer surface, identified by stratigraphy in snow pits and by probing. Snow density was measured using samples from pit walls and from cores. The 


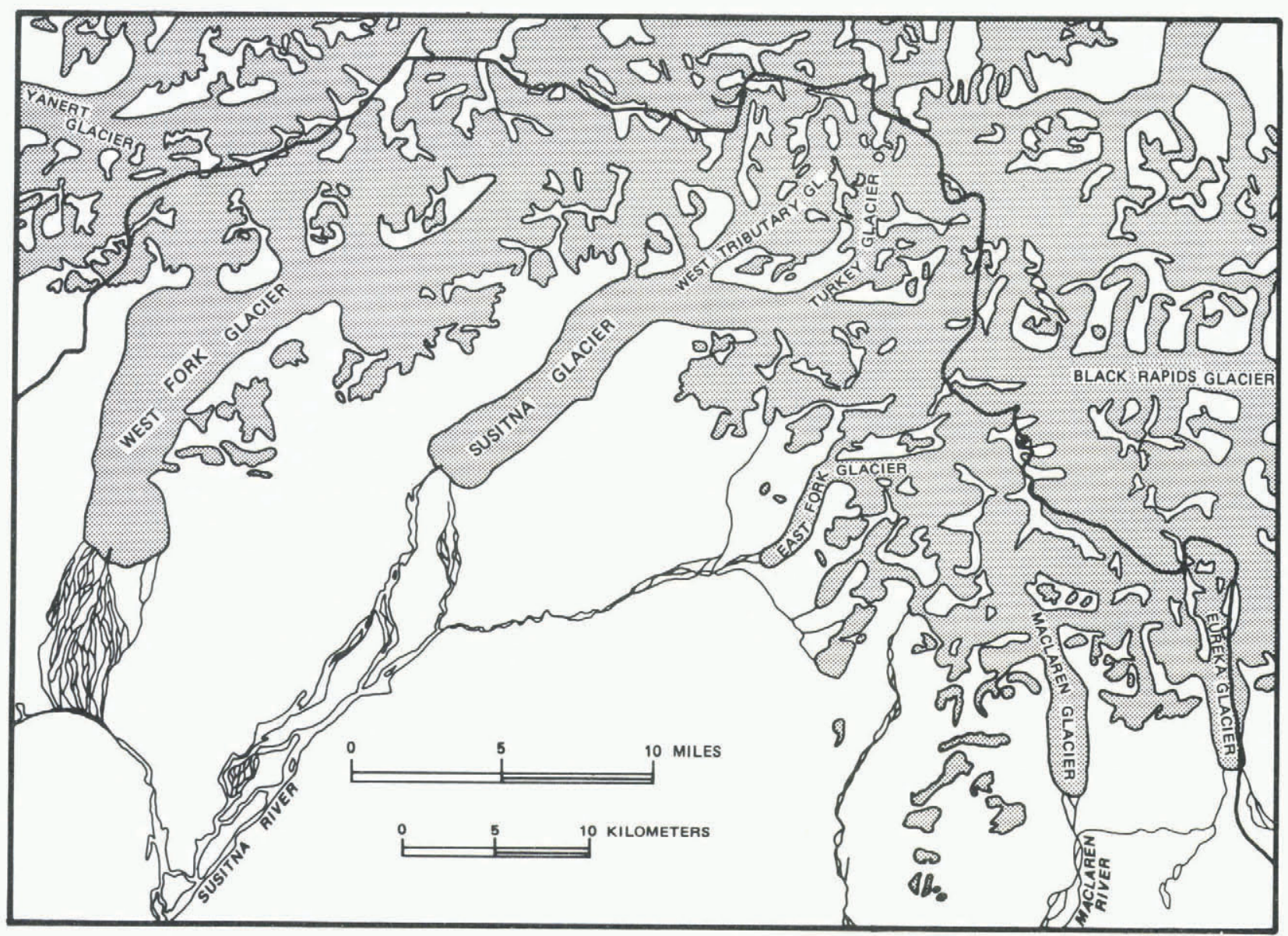

Fig.2. Glacierized area of Susitna basin in Alaska Range. Additional glacierized area (1 or $2 \%$ of that shown) is in the Talkeetna Mountains to the south of the Susitna River. From USGS Healy and Mt Hayes quadrangles.

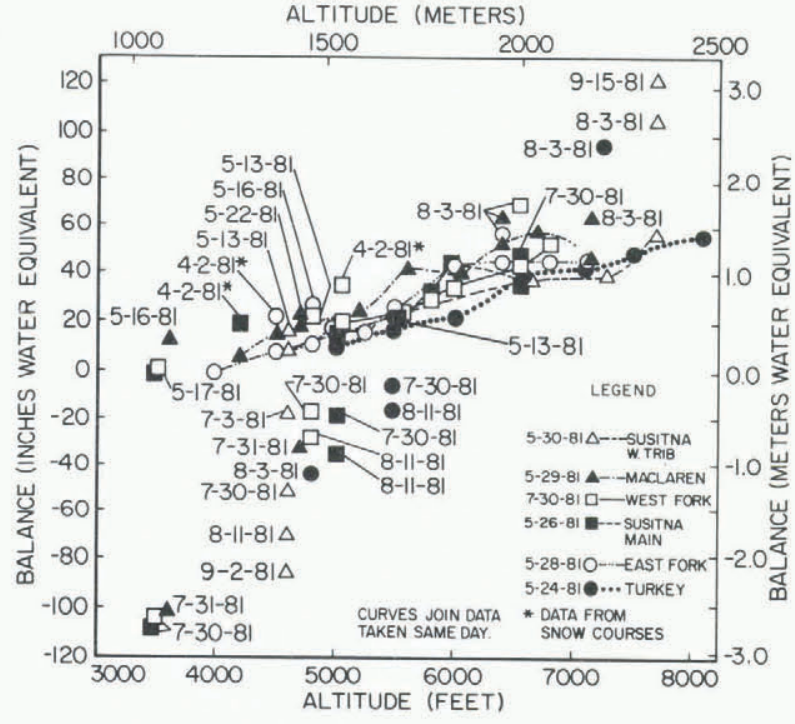

Fig.3. Balance-altitude data for glaciers of the Susitna basin, 1981.

errors are probably dominated by the accuracy of density interpolation at unmeasured sites. The altitudes in Figure 3 were read from topographic maps and may be too high by $60 \mathrm{~m}$ or more due to wasting of the glaciers, as discussed later. The May data do not quite represent winter balance at the lower elevations because ablation of roughly $0.30 \mathrm{~m}$ water equi- valent had already occurred there. The snow had become isothermal at $0^{\circ} \mathrm{C}$ by the time of the May survey. The late-summer snowline was at approximately $1830 \mathrm{~m}$ in 1981. Heavy snowfalls occurred in August and September at the higher altitudes.

An important feature of Figure 3 is the comparison which it gives of the balance-elevation data for the major Susitna basin glaciers. They are all rather similar, as is implicit in the foregoing discussion. However, there are differences. For example, winter balance is highest on Maclaren Glacier. 2.2. Change in glacier volume

To understand the hydrology of the basin it is important to make an estimate of the change in glacier volume during the period of stream gaging at Gold Creek (since 1949), because long-term estimates of water availability may be affected. For example, significant amounts of the measured flow may come out of the stored ice if glacier wasting has been severe. Photogrammetric estimates are possible because a vertical photo set taken in 1949 permits comparison with more recent ones. However, the resources at hand did not allow installation of ground control and new photography, and therefore the available data were not fully exploited. Instead, an estimate of the order of magnitude of possible volume change was made using existing uncontrolled photo sets taken in 1949 and 1980. East Fork Glacier, draining into the East Fork of the Susitna River (Figs.2 and 4), was chosen as a representative glacier because of its moderate size. It is also known as East Susitna Glacier. Rapid retreat is suggested by the high trimlines in Figure 4. Longitudinal profiles of its centerline surface altitude were constructed from the 1949 and 1980 photo sets (Fig. 5). 


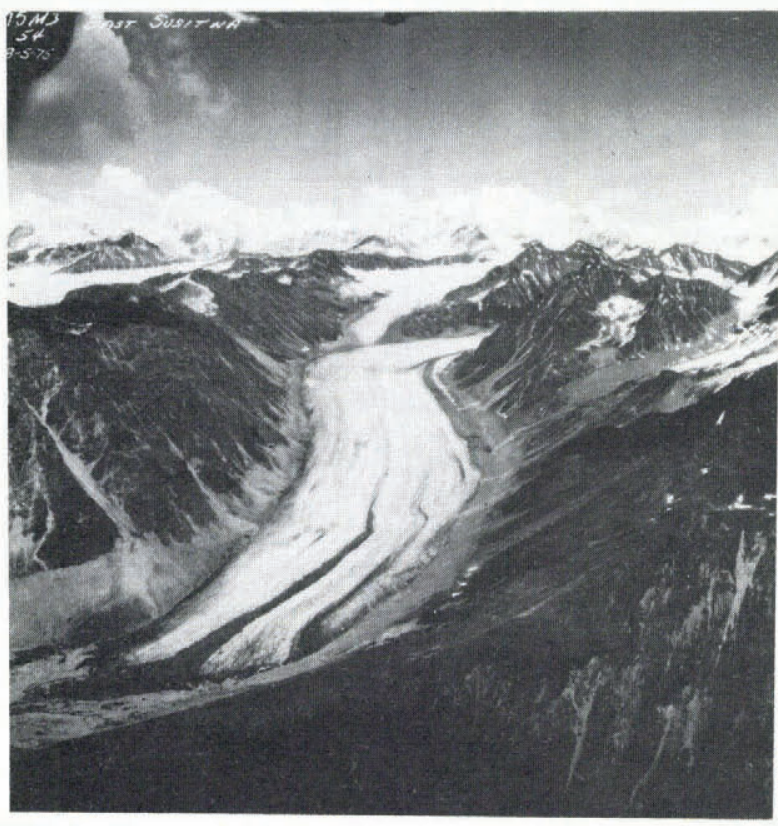

Fig.4. East Fork Glacier. (Photo by Lawrence Mayo.)

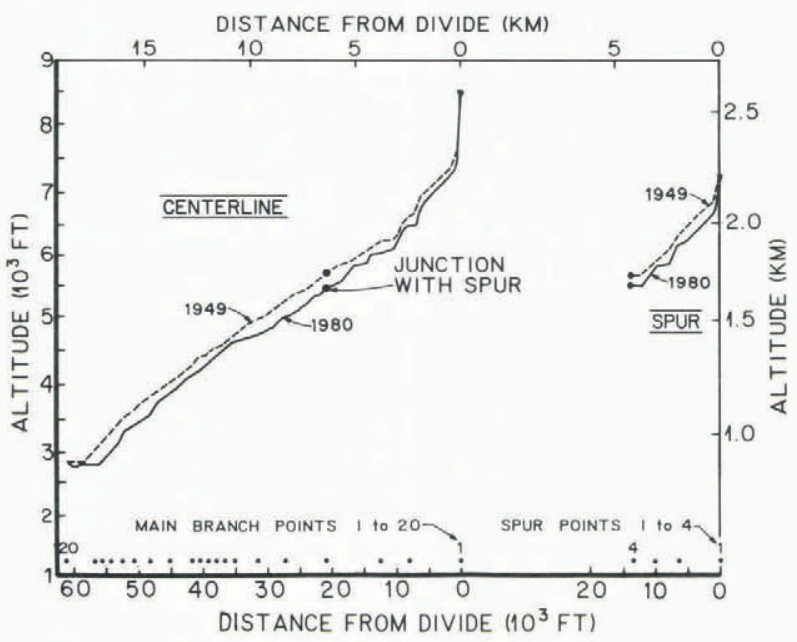

Fig.5. Surface altitude profiles along the centerline of East Fork Glacier in 1949 and 1980. The locations of the measured elevation points are shown.

An analysis of the altitude changes and of planimetric maps of the glacier in 1949 and 1980 indicates a decrease in surface altitude of about $50 \mathrm{~m}$ between 1949 and 1980, averaged over the surface area of the glacier of about $35 \mathrm{~km}^{2}$. Considering the estimated maximum altitude difference error of $18 \mathrm{~m}$, a statistical tendency for errors to cancel each other, and the limited data, the error in average altitude change could be $33 \%$ or more. It has two sources, the absence of any ground control other than that provided by existing topographic maps, and the lack of complete topographic mapping, only the profiles of altitude at the glacier centerline being measured. The first problem is ameliorated somewhat because altitude changes, rather than absolute altitudes, are of primary interest. The second problem is complicated by the fact that limited elevation data were obtained in the high basins, although a centerline elevation profile was also measured up a tributary basin (see Fig.5). In some places the elevation change exceeds $76 \mathrm{~m}$.
Over the period from 1966 to 1977 , Gulkana Glacier, situated $59 \mathrm{~km}$ to the east of East Fork Glacier, lost an average ice equivalent thickness of only about $0.34 \mathrm{~m} \mathrm{a}^{-1}$ (Meier and others 1980), while, over the period from 1949 to 1980, East Fork Glacier lost an average of roughly $1.6 \mathrm{~m} \mathrm{a}^{-1}$. It is not yet known if Gulkana Glacier can serve as an index glacier for the glaciers of the Susitna basin. If so, the comparison indicates a very rapid volume loss befure 1966 or that the error in the estimate for East Fork Glacier is larger than anticipated. Care needs to be exercised in extrapolating the change of East Fork to the other glaciers of the Susitna basin, particularly since East Fork represents only $5 \%$ of the total glacierized area, for reasons discussed by Meier (1966). However, we have attempted to estimate the order of magnitude of the contribution to runoff from glacier wasting, merely assuming that all the glaciers have lost the same average thickness as East Fork. The result suggests that stored ice has contributed about 13\% of total flow at Gold Creek since 1949. Although the accuracy limitation is severe, it nevertheless appears that the contribution to total flow from stored ice may have been significant. The danger of projecting future water supply from a glacierized basin without taking into account glacier wasting, which is not an unprecedented problem, is therefore indicated.

2.3. Susitna basin boundary

Evidence for instability in the drainage of the basin occupied by Eureka Glacier, on the eastern boundary of the Susitna basin (Fig.2), was noticed during a reconnaissance flight in August 1981. At present the drainage is divided between the Susitna and Delta rivers, with probably more than $50 \%$ going into the Susitna. It appears that most of this drainage could be captured by one river or the other, particularly since Eureka is a surging or pulsing glacier (Post 1969, Mayo 1978), and a pulse could rearrange the drainage. Inasmuch as this basin has an area of about $65 \mathrm{~km}^{2}$ and is probably subject to very high precipitation because most of it is at high altitude, the potential loss or gain of water is likely to be important.

\section{SEDIMENT}

An average rate of transport of suspended sediment of $7.0 \times 10^{6} \mathrm{t} \mathrm{a}^{-1}$ at Gold Creek was estimated in a separate study (R \& M Consultants 1982). Spot measurements of sediment transport were related to river discharge through a simple power-1aw rating curve, which was used to calculate the transport from the continuously measured discharge. Although this approach is reasonable, high accuracy is not expected because it is known that discharge and transport do not have a simple relationship ( $\varnothing$ strem and others 1967, Ziegler 1972, Østrem 1975, Walling 1977, Collins 1979). As a test, we have used a rating curve established from one set of daily measurements of suspended sediment made by the US Geological Survey in 1952 to predict the transport during another set made in 1957 ( $R$ \& M Consultants 1981). This gives only $44 \%$ of the measured rate of transport, which illustrates how complex the transport regime can be. It has been shown that $50 \%$ of the total annual transport in a glacier stream can occur in a single day $(\varnothing$ strem and others 1967). More relevant to the Susitna basin is that glacier surges may complicate the picture. It is not known how much sediment is released by a surge, but it may be very large (Uskov and Kvachev 1979 Shcheglova and Chizhov 1981).

These uncertainties are less serious than it may seem, because of the large reservoir size. Given reasonable estimates for the trap efficiencies of the Watana and Gold Creek reservoirs, the estimated sediment deposition in Watana is only $5 \%$ of reservoir volume per century, and in Devil Canyon $14 \%$ ( $R$ \& $M$ Consultants 1982). 


\section{GLACIER OUTBURST FLOODS}

Several glacier-dammed lakes have been mapped in the Susitna basin by Post and Mayo (1971) on West Fork and Maclaren glaciers, and the downstream areas are mapped as flood courses. Because the lakes are comparatively small, the larger ones being characteristically $600 \mathrm{~m}$ across, their effect on estimates of the probable maximum flood has been neglected so far. With or without surges lake conditions could change considerably during the life of the Susitna project (Dolgoushin and Osipova 1975), and some surveillance will probably be necessary.

\section{GLACIER CHARACTERIZATION}

As part of our reconnaissance of the glaciers of the Susitna basin we are attempting a general characterization. The results so far and some of their implications are discussed in the following sections. 5.1 . Mass balance

The balance data for 1980 to 1981 have already been presented.

\subsection{Thermal regime}

A thermocouple string placed in a hole at $20 \mathrm{~m}$ depth on the west tributary of Susitna Glacier $2350 \mathrm{~m}$ on 22 May, 1981 showed isothermal conditions $\left(0^{\circ} \mathrm{C}\right)$ to that depth at least by 3 August. Given the existing body of experience relating to heat transfer in glaciers (Paterson 1981), and the fact that most of the ice in the basin exists below this elevation, it is a reasonable inference that most of the glacier ice in the Susitna basin is temperate; that is, it is in equilibrium with liquid water (see Harrison 1975 , for example). Similar results have been found for Black Rapids and Gulkana glaciers to the east of the Susitna basin (Harrison and others 1975). The highest and the lowest parts of glaciers are often the coldest. In the ablation area of Black Rapids Glacier just to the east of the Susitna basin a surface layer probably $30 \mathrm{~m}$ or less thick is several degrees below freezing point. Surging may complicate the thermal regimes of the glaciers of the Susitna basin (Jarvis and Clarke 1974).

\subsection{Glacier dynamics}

Instability of their ice-flow regimes seems to be the rule for all the major glaciers of the Susitna basin. Probably all of them are surging glaciers (Meier and Post 1969, Post 1969, Mayo 1978), which means that they are subject to periodic episodes of rapid motion that bear no direct relation to climate. The definition of surges is not easy. At the one extreme a surge implies a catastrophic advance; at the other extreme it implies a weaker and short-lived pulse of motion. Susitna Glacier, which underwent a major surge in 1952 or 1953 (Post 1960), is in the former category; Maclaren Glacier, and probably Eureka and East Fork glaciers, would be in the latter. The situation seems to suffer from lack of published information on past surge histories, and from the fact that major surges of large glaciers occur infrequently, perhaps every 50 years or so.

The famous moraine patterns on Susitna Glacier give information about its surge history. Figure 6 shows them before and after the 1952 (or 1953) surge and in 1980. If the patterns always appear similar just before a surge, it is evident that no surge is imminent. Probably the next surge of Susitna Glacier is decades in the future, but there is no doubt that major surges, probably of several glaciers, will occur during the lifetime of the proposed Susitna project. The effects of surges on the project cannot be predicted in detail, particularly since few accessible data exist on the sediment and water discharges associated with surges. Most of the potential effects of surges have been noted earlier: possible large sediment discharge, formation of glacier-dammed lakes, possible loss of drainage from Eureka Glacier, and temporary increase of water production due to an increased area of ablation.

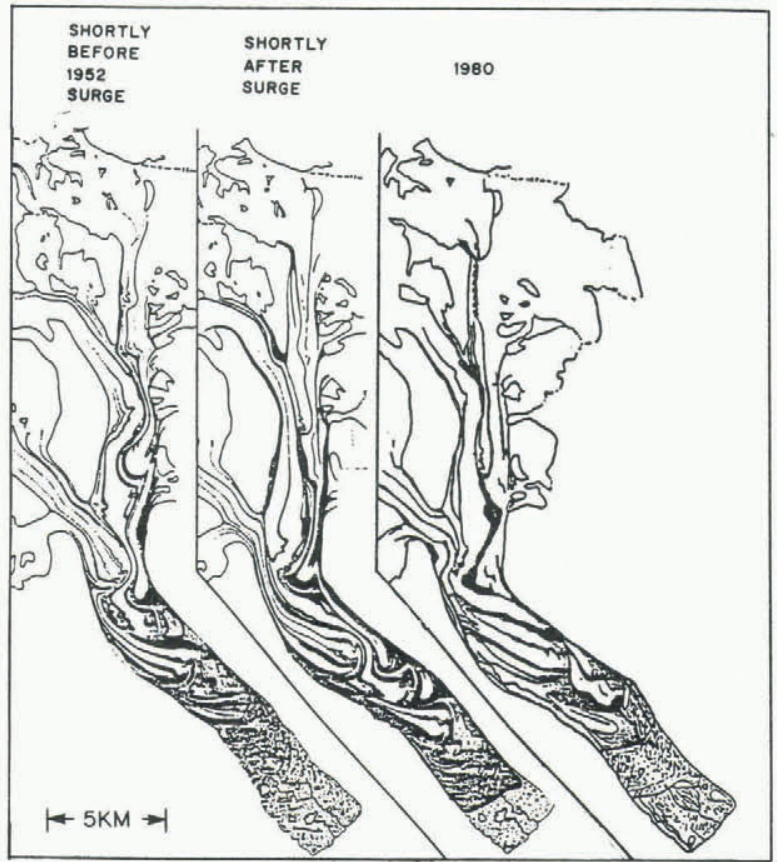

Fig.6. Evolution of moraine patterns on Susitna Glacier. Left and center diagrams from Meier and Post (1969). Right diagram sketched from National Aeronautics and Space Administration photographs.

In order to understand the flow regimes better, measurements of surface velocity on several of the major glaciers are underway. The results to date, all obtained near the equilibrium line, are in Table I.

TABLE I. DATA ON HORIZONTAL VELOCITY FOR GLACIERS OF THE SUSITNA GLACIERS, 1981*

$\begin{array}{llcc}\text { Glacier } & \begin{array}{c}\text { Measurement } \\ \text { interval }\end{array} & \begin{array}{c}\text { Velocity } \\ \left(\mathrm{m} \mathrm{d}^{-1}\right)\end{array} & \begin{array}{c}\text { Velocity } \\ \text { azimuth } \\ \left({ }^{\circ}\right)\end{array} \\ \begin{array}{l}\text { Susitna } \\ \text { (main branch) }\end{array} & \begin{array}{l}18 \text { May to } \\ \text { 2 Sept }\end{array} & 0.141 & 271.4 \\ \begin{array}{c}\text { Susitna } \\ \text { ("Turkey" } \\ \text { tributary) }\end{array} & \begin{array}{l}18 \text { May to } \\ \text { 3 July }\end{array} & 0.786 & 199.4 \\ & \begin{array}{l}\text { 3 July to } \\ \text { 30 July }\end{array} & 0.653 & 199.1 \\ & \begin{array}{l}30 \text { July to } \\ \text { 2 Sept }\end{array} & 0.529 & 199.8 \\ & \begin{array}{l}30 \text { May to } \\ \text { Susitna } \\ \text { (west } \\ \text { tributary) }\end{array} & 0.373 & 222.9 \\ & \begin{array}{l}\text { 3 July to } \\ \text { 2 Sept }\end{array} & 0.306 & 222.7 \\ \text { West Fork } & \begin{array}{l}17 \text { May to } \\ \text { 30 July }\end{array} & 0.227 & 262.7 \\ & & & \end{array}$

They indicate that large temporal changes in velocity occur, and therefore that sliding at the bed is probably an important ingredient of the motion of at least some of the glaciers of the Susitna basin.

* Measurement sites are at the equilibrium lines. 


\section{ACKNOWLEDGEMENTS}

We are grateful for the perspective provided by Carl Benson, Lawrence Mayo and Gerd Wendler, for the contributions of Roman Dial, Gary Bender and John Power, and for the cooperation of Acres American Inc. The financial support was from the State of Alaska.

\section{REFERENCES}

Acres American Inc. 1982 Susitna hydroelectric project; feasibility report. Final draft report for Alaska Power Authority, Anchorage, AK. 8 vols

Collins D N 1979 Sediment concentration in melt waters as an indicator of erosion processes beneath an alpine glacier. Journal of Glaciology 23(89): 247-257

Dolgoushin L D, 0sipova G B 1975 Glacier surges and the problem of their forecasting. Inter national Association of Hydrological Sciences Publication 104 (General Assembly of Moscow 1971 - Snow and Ice): 292-304

Harrison W D 1975 Temperature measurements in a temperate glacier. Journal of Glaciology 14(70): 23-30

Harrison W D, Mayo L R, Trabant D C 1975 Temperature measurements on Black Rapids Glacier, Alaska, 1973. In Weller G, Bowling S A (eds) Climate of the Arctic. Proceedings of the 24th Alaska Science Conference. Fairbanks, AK, University of Alaska. Geophysical Institute: 350-352

Jarvis G T, Clarke G K C 1974 Thermal effects of crevassing on Steele Glacier, Yukon Territory, Canada. Joumal of Glaciology 13(68): 243-254

Mayo L R 1978 Identification of unstable glaciers intermediate between normal and surging glaciers. Materialy Glyatsiologicheskikh Issledovaniy. Khronika. Obsuzhdeniya 33: 133-135

Meier M F 1966 Some glaciological interpretations of remapping programs on South Cascade, Nisqually, and Klawatti glaciers, Washington. Canadian Jourmal of Earth Sciences 3(6): 811-818

Meier M F 1969 Glaciers and water supply. Joumal of the American Water Works Association 61(1): 8-12

Meier M F, Post A S 1969 What are glacier surges? Canadian Journal of Earth Sciences 6(4): 807-817

Meier M F, Tangborn W V 1961 Distinctive characteristics of glacier runoff. US Geological survey. Professionat Paper 424-B: 14-16

Meier M F, Mayo L R, Trabant D C, Krimmel R M 1980 Comparison of mass balance and runoff at four glaciers in the United States, 1966 to 1977. Materialy Glyatsiologicheskikh Issledovaniy. Khronika. Obsuzhdeniya 38: 214-216

Østrem G 1975 Sediment transport in glacial meltwater streams. In Jopling A V, MacDonald B C (eds) Glaciofiuvial and glaciolacustrine sedimentation. Tulsa, OK, Society of Economic Paleontologists and Mineralogists: 101-122 (Special Publication 23)

Østrem G, Bridge C W, Rannie W F 1967 Glaciohydrology, discharge and sediment transport in the Decade Glacier area, Baffin Island, N.W.T. Geografiska Annater 49A(2-4): 268-282

Paterson W S B 1981 The physics of glaciers. Second edition. 0xford, Pergamon Press

Post A S 1960 The exceptional advances of the Muldrow, Black Rapids, and Susitna glaciers. Journal of Geophysical Research 65(11): 3703-3712

Post A S 1969 Distribution of surging glaciers in western North America. Joumal of Glaciology 8(53): 229-240

Post A S, Mayo L R 1971 Glacier dammed lakes and outburst floods in Alaska. Washington, DC, US Geological Survey (Hydrologic Investigations Atlas HA-455)

R \& M Consultants Inc. - W D Harrison 1981 Alaska Power Authority Susitna hydroelectric project; task 3 - hydrology; glacier studies. Report for Acres American Inc., Buffalo, NY
R \& M Consultants Inc. 1982 Alaska Power Authority Susitna hydroelectric project; task 3 - hydrology; subtask 3.07 - closeout report - reservoir sedimentation. Report for Acres American Inc., Buffalo, NY

Shcheglova O P, Chizhov O P 1981 Sediment transport from the glacier zone, central Asia. Annals of Glaciology 2:103-108

Uskov Yu S, Kvachev V I 1979 Pul'siruyushchiy lednik Didal' [The Didal surging glacier]. Materialy Glyatsiologicheskikh Issledovaniy. Khronika. Obsuzhdeniya 36: 170-175

Walling DE 1977 Assessing the accuracy of suspended sediment curves for a small basin. Water Resources Research 13(3): 531-538

Ziegler T (ed) 1972 Slamtransportunders $\varnothing$ kelser i norske bre-elver 1970. Norges Vassdrags- og Elektrisitetsvesen. Vassdragsdirektoratet. Hydrologisk Avdeling. Rapport 1-72 